\title{
'Red Tide' Menace Spreads to the Indian Subcontinent's Largest Natural Freshwater Lake
}

$\mathrm{K}_{\mathrm{s}}^{\mathrm{a}}$ ashmir, a beautiful valley that is partially isolated by snow-capped Himalayan mountainous ranges, is blessed with an array of fascinating natural lakes. Several of these lakes, in the recent past, have fallen victim to human greed and apathy, thereby endangering the very survival of these natural resources. Thus Dal Lake, once a pristine waterbody, developed a temporary and short-phased massive red-bloom of a rare euglenoid flagellate (Euglena pedunculata Gojdics) during the summer-autumn of 1991, rendering its surface waters murky.

Notwithstanding the speculative status of the flagellate's colonization in such an isolated habitat as Dal Lake, the organism gained wider proliferation, carving out additional ecological niches in other floodplain lakes of the Himalayan Jhelum Valley. One such lake that has been affected by the 'red tide' occurrence is the renowned highaltitude $(1,500 \mathrm{~m})$ Lake Wular $\left(31.1^{\circ} \mathrm{N}\right.$ and $\left.74^{\circ} \mathrm{E}\right)$, about $34 \mathrm{~km}$ to the northnorth-west of Srinagar, the summer capital of Jammu \& Kashmir State.

Lake Wular is considered to be the largest-area $(20,200$ ha) natural freshwater lake in India and probably in Asia. During floods, the Lake area even spreads over 26,700 ha (cf. W.R. Lawrence, 1992 - The Valley of Kashmir, Chinar Publishing House, Srinagar [reprint edn]). Besides its water-input from several springs and streams, Lake Wular is fed and drained primarily by the River Jhelum. However, the River also contributes significantly to the Lake's siltation problem, with the result that extensive peripheral areas have become converted to marshland and been reclaimed for cultivation of Rice (Oryza sativa), vegetables, or even willow (Salix spp.) plantations. There are recent reports (e.g. Kashmir Times, 31 January 1994) of shrinkage of the surface area of Lake Wular from 19,000 ha in 1991 to 7,900 ha in 1993 reduction to only about $41 \%$ of its former size, and highly alarming if true).

Added to the already deplorable plight of Lake Wular's health, the present Author, while surveying it on 7 September 1993, observed that vast expanses of the surface had turned red - a phenomenon earlier reported (see M.A. Khan, 1993, Environmental Conservation, 20[4], pp. 3526,5 figs) in Dal Lake, Srinagar. Such an observation, hitherto probably not documented for Lake Wular, signals rapid environmental deterioration of the ecocomplex, as euglenoids dwell mostly in organic-rich waters and are biological indicators of pollution.

Lake Wular is of great socio-economic importance, providing a good source of Water-nut (Trapa natens), fodder, and fish. The fisheries are made up of the Common Carp (Cyprinus carpio) (70-75\%) and many other species including the endemic trout. The Lake also serves as a breeding habitat for a large number of resident and migratory birds.

The need of the hour is to arrest the spreading menace of the red-tide phenomenon and combat the ecological deterioration of Lake Wular to salvage one of Asia's unique ecocomplexes from extinction.

M.A. KHAN, Reader (Ecology)
Department of Botany
University pf Kashmir
clo Post Box 726
GPO Srinagar 190001
Kashmir, India.

\section{Population Projections to the Year 2050: IIASA Scenarios for Europe and the World}

$\mathrm{W}$ hat might the population of Austria and other European countries be sixty years from now? Several scenarios which have been developed by the Population Project of the International Institute for Applied Systems Analysis (IIASA) raise questions about the future that are relevant today. The questions are crucial because some of the economic and political decisions of today have to be based on assumptions about the future. For example: how will pensions be financed in the year 2050, if the working population of Austria decreases from 4.3 millions to 3.5 millions, or even as low as 2.5 millions, and the proportion of elderly people increases from the present $20 \%$ to $40 \%$ ? These figures are realistic if one assumes that immigration stops and the currently low birth-rates persist.

\section{Population Ageing Problems}

The most dramatic demographic development in Europe is the rapid ageing of the population. Again using Austria as an example, the number of 80 years-old people in AD 2050 could be four times as high as it is today, although the total population may be lower. Such potentially large shifts call for important political decisions in areas such as health care, immigration, and equal employment opportunities - especially for women, so that they are able to devote time to both job and family.

These population projections include sensitivity analyses over a wide range of assumptions. The sensitivity tests show that, although the results vary depending on the assumptions, all the scenarios point to the urgent need to take political action.

Much has been said and written about the increasing ageing of Europe's population, but its implications are still vastly underestimated. It is almost certain that, if comprehensive pension reforms are not carried out soon, welfare systems of European states will face a deep crisis. However, the still-favourable situation over the next two decades provides a window of opportunity for decisive action.

\section{World Population Scenarios}

According to the scenarios developed at IIASA, total world population will increase by at least $50 \%$ by the year 2030 - up from the present 5.6 thousand millions to 8 thousand millions. The maximum likely increase is to 11 thousand millions, i.e. nearly $100 \%$. The most probable figure will be about 9.5 thousand millions (an increase of nearly $80 \%$ ). Thereafter, world population is projected to increase very slowly, to stabilize at around 12 thousand millions in the second half of the next century.

'The world population projections developed at IIASA account for a much wider range of possibilities than those of the UN and the World Bank', says Professor Wolfgang Lutz, Leader of IIASA's Population Project. 'They consider alternative future paths not only in fertility, but also in mortality and migration', he adds. In making these projections, the IIASA study also examines potential impacts of ecological constraints and new mortality risks such as AIDS - but not those of wars or internecine strife. 
All scenarios show significant population increases in the developing countries by $\mathrm{AD} 2030$, though Europe's share decreases from its present $14 \%$ to about $8 \%$ of world population. The projections also show that increased lifeexpectancy will lead to a rapidly-ageing population in developing countries. This will pose severe problems for which their social systems are at present unprepared.

These new world population scenarios show that future trends are not inevitable and there are significant opportunities to influence them. The forthcoming UN International Conference on Population and Development, to be held in Cairo during 5-13 September 1994, will provide an appropriate occasion to discuss these opportunities in an international forum.*

ELISABETH KRIPPL, Head
Public Information
International Institute for Applied
$\quad$ Systems Analysis (IIASA)
A-2361 Laxenburg
Austria.

* See also our book Environmental Challenges, II: Population and Global Security, designed primarily at enlightening ICPD participants on Population-Environment issues, and now fully in press. Ed.

\section{Climate Change Treaty Goes Into Effect}

$\mathrm{T}$ he United Nations Framework Convention on Climate Change entered into force on 21 March $1994-90$ days after receiving its 50th ratification and less than two years after it was signed by more than 150 Governments at the Rio 'Earth Summit'. This means that the treaty is now international law and legally binding on its Parties (i.e. ratifying countries), which already include most of the major emitters of 'greenhouse' gases.

The treaty commits developed-country Parties to take measures aimed at returning their emission of carbon dioxide and other 'greenhouse' gases to AD 1990 levels by the year 2000. They were given just six months (until 21 September 1994) to submit information explaining how they plan to meet this and other Convention obligations. These other commitments include protecting and enhancing 'greenhouse' gas 'sinks' and 'reservoirs' (such as forests that absorb carbon dioxide from the atmosphere) and providing financial and technological resources to help developing countries to adapt to climate change and implement the treaty.

\section{Less-developed Countries Favoured}

As for 'developing' countries, they are not required to limit their emissions. However, they (along with developed countries) have accepted commitments to: draw up 'inventories' listing the sources and quantities of their national 'greenhouse" gas emissions, carry out national programmes for mitigating climate change and adapting to its effects, strengthen their scientific and technical research activities, and promote education and public awareness programmes about climate change.

Carbon dioxide is the biggest immediate challenge for developed countries. Most $\mathrm{CO}_{2}$ is emitted by the burning of fossil fuels (oil, gas, and coal), although deforestation and other land clearances also contribute. The national reports that developed countries will soon submit (and update at regular intervals) are likely to describe a mix of regulatory, voluntary, and other, measures for encouraging industry, power stations, households, public authorities, and the transport sector, to control their emissions.

Though prepared for an international forum, these national reports should be essential reading for national policymakers and the informed public. It is at this level of individuals changing how they use energy in their homes and daily lives, of companies responding to incentives for technological innovation and energy conservation, and of local politicians introducing energy-efficiency into transport networks and building codes - that the Climate Change Convention will become a reality for most people. As of early March 1993, two countries (Canada and the
UK) had already submitted their reports under the Convention. Other countries have also published preliminary information; they include Australia, Cuba, the Czech Republic, Germany, Ireland, Italy, Japan, The Netherlands, New Zealand, Norway, Slovakia, Switzerland, and the US.

Meanwhile it has become widely recognized by Governments that bringing developed country emissions back to their AD 1990 levels by the year 2000 will not be enough to achieve the Convention's objective of stabilizing 'greenhouse gas concentrations in the atmosphere at a level that would prevent dangerous anthropogenic interference with the climate system', says Professor Bert Bolin, a leading international scientist from Stockholm, Sweden, who is Chairman of the Intergovernmental Panel on Climate Change (IPCC), which produces highly-influential scientific and technical assessment reports: for 'Stabilizing developed-country emissions of carbon dioxide, as is [currently] being aimed-for, is only a very modest first step towards stabilizing atmospheric concentrations of this gas. Because $\mathrm{CO}_{2}$ emissions remain for such a long time in the atmosphere; even stabilizing total global emissions would not stabilize atmospheric concentrations for several hundred years.'

Professor Bolin highlights total global emissions because, under the treaty, only developed countries must aim to stabilize their emissions. The Convention accepts that the first priority of developing countries is their own economic and social development, and that their emissions will rise as they industrialize. As a result, although developed countries aim to stabilize or even reduce their emissions, total global emissions will still continue to rise. This is why breaking the link between economic development and 'greenhouse' gas emissions is the fundamental, long-term challenge facing the world community.

\section{First Review in March 1995}

According to the treaty, the adequacy of developedcountry commitments must be reviewed at the first session of the Conference of the Parties (COP), the body that will be responsible for overseeing the implementation of the Convention. This session is scheduled for March 1995 in Berlin, Germany. The review will be based in part on a Special Report that the IPCC plans to release, in November 1994 , to update its assessment of the work that is being conducted at research and monitoring centres around the world into the causes and impacts of climate change. The review will also consider the effectiveness of developedcountry efforts to limit emissions as described in the national reports. 